\title{
Report Version Communication Mode Code
}

National Cancer Institute

\section{Source}

National Cancer Institute. Report Version Communication Mode Code. NCI Thesaurus.

Code C94057.

A coded value specifying the form in which the report is transmitted. 